\title{
Chronic idiopathic polyneuropathy treated with azathioprine
}

\author{
B PENTLAND, GGW ADAMS, CMAWDSLEY \\ From the University Department of Medical Neurology, Northern General Hospital, Ferry Road, Edinburgh
}

SUMMARY The results of azathioprine therapy in five patients with chronic progressive or relapsing idiopathic inflammatory polyneuropathy are described. In four patients a sustained improvement followed treatment and in the other patient azathioprine successfully replaced corticosteroid therapy. The improvement was often delayed for up to three months. The literature on the use of azathioprine in chronic polyneuropathy is reviewed. We suggest that there is a place for azathioprine treatment in patients with chronic idiopathic polyneuropathy resistant or intolerant to corticosteroid treatment.

Chronic idiopathic or inflammatory polyneuropathy is less common than the acute polyneuropathy of Guillain and Barré, but it does appear to be a variant of the same condition. ${ }^{12}$ In both forms findings include predominantly motor involvement with proximal as well as distal muscles affected; diminished or absent tendon reflexes; high cerebrospinal fluid protein and delayed nerve conduction. ${ }^{3}$ Experimental allergic neuritis provides a useful animal model for acute inflammatory polyneuropathy and usually follows an acute monophasic course ${ }^{4}$ but some experimental animals follow a chronic progressive or relapsing course similar to the chronic disorder in humans. ${ }^{5} \mathrm{~A}$ cell mediated hypersensitivity reaction is an important pathogenic mechanism in the experimental models.

Although corticosteroid treatment in acute polyneuropathy is of doubtful value ${ }^{6}$ many reports indicate that such treatment is useful in chronic polyneuropathy. ${ }^{7-10}$ Reports on the use of other immunosuppressants in treating chronic idiopathic polyneuropathy are few. We describe our experience of azathioprine treatment in five patients with chronic idiopathic polyneuropathy and review the literature.

\section{Patients and methods}

The five patients described were all admitted to the medical neurology department of the Northern General Hospital, Edinburgh. The diagnostic criteria employed in our unit

Address for reprint requests: Dr B Pentland, Northern General Hospital, Ferry Road, Edinburgh EH5 2DQ, Scotland.

Received 13 March 1982 and in revised form 28 May 1982. Accepted 6 June 1982 for chronic idiopathic polyneuropathy are as follows: (1) Presence of a predominantly motor polyneuropathy with a tendency to proximal as well as distal motor involvement, (2) A course that is steadily progressive or relapsing and remitting for a period of six months, or longer, (3) Elevated cerebrospinal fluid (CSF) protein without a significant increase in cell count, (4) Marked slowing of nerve conduction velocity, (5) Absence of associated disease with the exception of a short lived inflammatory illness preceding or in the initial stages of the disorder, (6) Haemoglobin, white cell count, erythrocyte sedimentation rate, serum urea, electrolytes, liver function tests, calcium, phosphate and immunoglobulin electrophoresis and urinalysis, including porphyrins, normal. The duration of disease before azathioprine treatment, the highest level of CSF protein and the slowest recordable motor nerve conduction velocity for the five patients are given in table 1 .

\section{Case reports}

Case 1 This patient has been described in detail elsewhere in the past." She presented aged eighteen years, in December 1964, with clumsiness and distal weakness from which she recovered over a few months without drug treatment. There was a further relapse with spontaneous improvement in February 1967. In September 1967, she had a severe relapse and required ventilation but appeared to respond dramatically to ACTH therapy. During the years from 1968 to 1972, she had a further three relapses with loss of response to ACTH. For the next five years she had relapses lasting one to six months with partial remissions of one to four months. Treatment with high dose intravenous methylprednisolone seemed effective, but she never maintained the improvement despite trials of ACTH, tetracosactrin, dexamethasone and prednisolone. During the latter half of 1977 , she showed a steady decline, culminating in admission with profound weakness which necessitated assisted ventilation. Azathioprine treatment 
Table 1 Patients with chronic idiopathic polyneuropathy

\begin{tabular}{|c|c|c|c|c|c|c|}
\hline Patient & $\begin{array}{l}\text { Age at onset } \\
(y r)\end{array}$ & Sex & $\begin{array}{l}\text { Highest CSF } \\
\text { protein }(g / l)\end{array}$ & $\begin{array}{l}\text { Slowest recordable } \\
N C V(m / s)\end{array}$ & $\begin{array}{l}\text { Duration of illness } \\
\text { before azathioprine }\end{array}$ & $\begin{array}{l}\text { Highest dose of } \\
\text { azathioprine ( } \mathrm{mg} / \mathrm{dy} \text { ) }\end{array}$ \\
\hline $\begin{array}{l}1 \\
2 \\
3 \\
4 \\
5\end{array}$ & $\begin{array}{l}18 \\
24 \\
47 \\
43 \\
62\end{array}$ & $\begin{array}{l}\mathbf{F} \\
\mathbf{F} \\
\mathbf{M} \\
\mathbf{M} \\
\mathbf{M}\end{array}$ & $\begin{array}{l}1 \cdot 19 \\
1 \cdot 91 \\
1 \cdot 90 \\
3 \cdot 68 \\
1 \cdot 76\end{array}$ & $\begin{array}{r}13 \\
9 \\
23 \\
16 \\
29\end{array}$ & $\begin{array}{l}13 \text { years } \\
5 \text { years } \\
10 \text { years } \\
5 \text { months } \\
10 \text { months }\end{array}$ & $\begin{array}{l}200 \\
200 \\
200 \\
300 \\
200\end{array}$ \\
\hline
\end{tabular}

$\mathrm{NCV}=$ Motor nerve conduction velocity.

was established in December with the dose gradually increased to $200 \mathrm{mg}$ daily. Within six months she was walking unaided and power and reflexes had returned gradually. She was maintained on azathioprine alone until December 1979, and after that she remained completely recovered except for occasional slight paraesthesiae until May 1981, when she began to notice some numbness and weakness distally. Azathioprine was reinstated in early June, and within the month she had recovered.

Case 2 This 24-year-old housewife was admitted in August 1975. She had been well until the fifth month of her first pregnancy in June 1974, when she developed weakness of the right leg and diplopia. Without treatment she successfully completed her pregnancy and her diplopia disappeared but she continued to suffer from slight weakness of the leg. In March 1976, she felt her arms gradually get weaker and clumsy and both legs became weaker. She was admitted to the local hospital in May, and found to have bilateral foot drop with general weakness of the upper limbs and reduced tendon jerks. CSF protein was $2 \mathrm{~g} / \mathrm{l}$ with no increase in cells and polyneuropathy was diagnosed. There was no response to oral prednisolone and her condition fluctuated so that she was referred to our unit. On admission to the neurological unit in August 1975, she had profound weakness and was unable to weight bear or feed herself; there was a left lateral rectus palsy with papilloedema; she was areflexic and had glove and stocking sensory loss. High dose prednisolohe therapy was maintained and by November, she was able to feed herself, comb her hair and take a few steps with a walking frame. A month later she was walking without aid but still had bilateral foot drop. Throughout the following year she made a slow but steady improvement without further treatment, and by the end of the year could run and was able to cope with part-time employment. In May 1977, she again developed diplopia, right leg weakness and peripheral paraesthesiae and the weakness spread over the next three months by the end of which time she became unable to walk outdoors. By February 1978, she was unable to do even light household tasks and remained severely incapacitated during the following year. Her weakness progressed further in 1979, and she was re-admitted to the unit and needed assisted ventilation for several weeks. Although she showed some improvement she remained profoundly weak and in September 1979, azathioprine therapy was started. Within a month there was improvement in motor function and by December 1979, she was markedly improved and walking without support. Her improvement was maintained and at subsequent reviews in September 1980, and July 1981, she was leading a fully independent life with only slight distal weakness while continuing on azathioprine therapy alone.

Case 3 This 47-year-old engineer first attended the department in May 1978. Ten years before this he had had an upper respiratory tract infection which had been followed by paraesthesiae and weakness of his arms which lasted a few weeks but recovered without treatment. In 1970 , he had a recurrence of paraesthesiae in his hands and feet with distal weakness and loss of balance. He was admitted to another neurological unit and was found to have bilateral foot drop and reduced tendon reflexes, raised CSF protein and delayed nerve conduction. He was given a month's course of ACTH and improved but several months later his symptoms recurred. He was treated with oral prednisolone which was continued for one year with gradual improvement in his symptoms. The steroids were withdrawn in November 1972, and he remained well. In 1976, after a 'flu-like illness paraesthesiae recurred and only slight improvement followed prednisolone therapy. He continued on prednisolone and was referred to our unit in May 1978. Despite maintenance of prednisolone therapy his paraesthesiae became worse in October 1978, and so azathioprine was started in a dose of $150 \mathrm{mg}$ daily. Nine months later he was no better and the azathioprine dose was increased to $200 \mathrm{mg}$ daily. His paraesthesiae were much reduced within two months of this and the azathioprine was successfully withdrawn in September 1980, two years after its institution. At review in April 1981, he was much improved, although he remained areflexic. His only complaint was of occasional slight numbness in his feet.

Case 4 A 43-year-old aircraft fitter presented to another neurological unit in April 1979, with a three week history of peripheral paraesthesiae and progressive weakness following a short diarrhoeal illness. The weakness spread from distal to proximal muscles and he had left facial weakness. The reflexes were absent and there was reduced vibration sense in the lower limbs. His CSF protein was $2 \cdot 8$ $\mathrm{g} / \mathrm{l}$. A diagnosis of Guillain-Barré syndrome was made and treatment was started with ACTH, 60 units daily. Four months prior to presentation he had had a three week episode of right facial weakness which resolved spontaneously. He was transferred to our unit in May 1979, to be nearer his family. His ACTH treatment was gradually reduced and was stopped in mid-June. Within a day he deteriorated rapidly and required assisted ventilation for two weeks. ACTH therapy was reinstituted and azathioprine given in a dose of $200 \mathrm{mg}$ daily. He improved over the next two months but relapsed again in early August despite 
continuing therapy. The azathioprine dose was increased to $300 \mathrm{mg}$ daily, and he was also given oral prednisolone $60 \mathrm{mg}$ daily. He improved over the next month but azathioprine had to be stopped because of leucopenia. Within a week he had deteriorated so that he required assisted ventilation. Azathioprine treatment was re-established in combination with prednisolone and by the end of November he was showing steady significant improvement. He was sufficiently recovered to be allowed home by the end of the year. He continued to take azathioprine and prednisolone until June 1980. By that time he was dramatically improved and was taking regular walks of half a mile with the aid of a stick. He has been seen regularly since then and his only clinical findings have been areflexia, bilateral foot drop and reduced sensation in the feet. In June 1981, he was back in full time employment. He continues to take $100 \mathrm{mg}$ azathioprine and $4 \mathrm{mg}$ prednisolone.

Case 5 A 62-year-old retired bank manager presented with a two month history of weakness in his arms and legs in October 1979. The weakness was most marked proximally in the arms. The reflexes in the upper limb were absent and those in the lower limbs were just elicitable. Prednisolone therapy was started in November, and there was some improvement within a few days but thereafter his power fluctuated considerably. By April 1980, he was able to walk only a few steps. Whilst still taking prednisolone he relapsed in July 1980, with the development of marked weakness and his ventilatory function was sufficiently impaired for assisted ventilation to be considered although it did not prove necessary. Azathioprine therapy was started in a dose of $200 \mathrm{mg}$ daily together with $25 \mathrm{mg}$ prednisolone daily. Within a few days there was improvement which increased and was maintained. By October 1980, he was walking with support but two months after this he was able to climb stairs and get in and out of the bath unaided. In January 1981, he was walking outdoors with a stick and by March, the stick was no longer required. At his last review in May 1981, he was maintaining the improvement on $100 \mathrm{mg}$ azathioprine and $10 \mathrm{mg}$ prednisolone daily.

\section{Discussion}

We have described five patients with chronic idiopathic polyneuropathy treated with azathioprine. In four patients a sustained improvement followed treatment and in the other patient (Case 3) azathioprine successfully replaced corticosteroid therapy. The improvement following azathioprine usually occurred after a few weeks but could be delayed for as long as three months. Azathioprine is an antilymphocytic agent and a delay before it exerts clinical effects is well recognised. As the immunosuppressive effect of azathioprine does not correlate well with peripheral white blood cell count reduction it was our policy to give doses not exceeding $4 \mathrm{mg} / \mathrm{kg}$ body weight and to maintain patients on the lowest dose consistent with sustained clinical benefit which was 100 to $200 \mathrm{mg}$ of azathioprine daily.

There have been no reports of controlled clinical trials of azathioprine in chronic idiopathic polyneuropathy. There have been a number of reports of its successful use in acute idiopathic polyneuropathy. ${ }^{12-14}$ The results of reported cases of azathioprine treatment in chronic idiopathic polyneuropathy are summarised in table $2 .{ }^{10}{ }^{15-18}$ Yuill et al described the treatment of one patient with chronic polyneuropathy but the patient tolerated the drug for a few days only. ${ }^{14}$ Cendrowski described six patients treated with azathioprine but three received it within six months of the onset of their polyneuropathy and another patient had polyarteritis nodosa. ${ }^{15}$ These four patients, therefore, are excluded from table 2 . In a recent report ${ }^{10}$ azathioprine therapy was described as successful in three out of four patients but details of only two patients were given. These two are included in table 2 . As other authors have noted clinical improvement in patients even in those who achieved full functional recovery was not, in some cases, reflected in the nerve conduction studies which remain impaired in four of our cases in which the studies were performed. ${ }^{10}$

Chronic idiopathic polyneuropathy is an uncommon disorder which often follows a relapsing and remitting course. Life-threatening ventilatory failure often supervenes. This makes the assessment of any form of therapy difficult. Controlled trials using placebo with an agent such as azathioprine which often has a delayed therapeutic effect, presents practical and clinical difficulties. Our experience and

Table 2 Reported cases of azathioprine treatment in chronic polyneuropathy

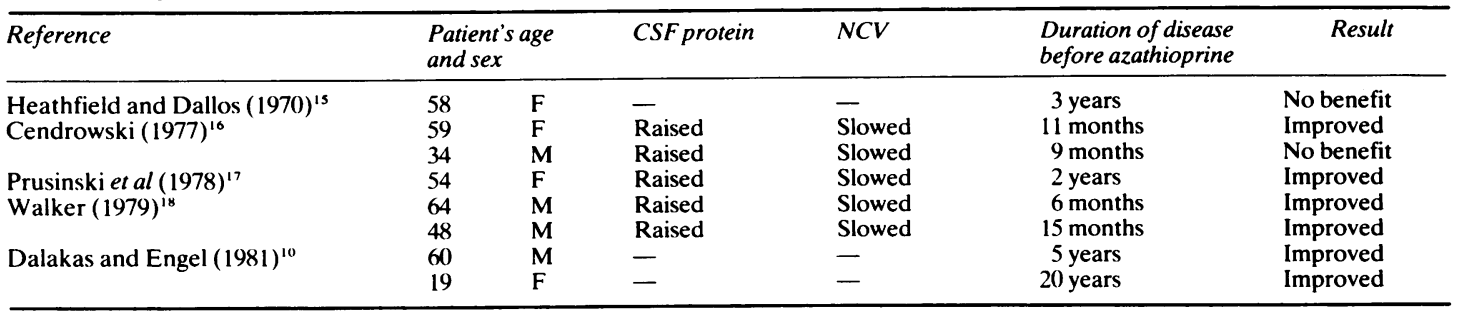

$\mathrm{NCV}=$ Nerve conduction velocity. 
that of others suggest that there is a place for the use of azathioprine in the treatment of chronic idiopathic polyneuropathy. Our policy is to give patients who fulfil the criteria of chronic idiopathic polyneuropathy a trial of corticosteroid therapy. We consider using azathioprine in those who do not respond and in those who require a high maintenance dose of corticosteroid with its inherent risks. Azathioprine is a potentially hazardous drug and we would emphasise the need for regular follow-up of patients receiving it with frequent monitoring of blood and platelet counts.

\section{References}

I Thomas PK, Lascelles RG, Hallpike JF, Hewer RL. Recurrent and chronic relapsing Guillain-Barré polyneuritis. Brain 1969;92:589-606.

2 Swash M. Clinical aspects of Guillain-Barré syndrome: a review. J $R$ Soc Med 1979;72:670-3.

${ }^{3}$ Dyck PJ, Lais AC, Ohta M, Bastron JA, Okazaki H, Groover RV. Chronic inflammatory polyradiculoneuropathy. Mayo Clin Proc 1975;50:621-37.

4 Arnason BGW. Inflammatory polyradiculoneuropathies. In: Dyck PJ, Thomas PK, Lambert EH, eds. Peripheral Neuropathy Vol 2. Philadelphia: WB Saunders, 1975:1110-48.

5 Pollard JD, King RHM, Thomas PK. Recurrent experimental allergic neuritis. An electron microscope study. J Neurol Sci 1975;24:365-83.
${ }^{6}$ Hughes RAC, Newsom-Davis JM, Perkin GD, Pierce JM. Controlled trial of prednisolone in acute polyneuropathy. Lancet 1978;2:750-3.

7 Austin JH. Recurrent polyneuropathies and their corticosteroid treatment. Brain 1958;81:157-94.

8 Matthews WB, Howell DA, Hughes RC. Relapsing corticosteroid dependent polyneuritis. J Neurol Neurosurg Psychiatry 1970;33:330-7.

9 Thomas PK. Peripheral neuropathy. In: Matthews WB, ed. Recent Advances in Clinical Neurology. Edinburgh: Churchill Livingstone, 1975:253-83.

10 Dalakas MC, Engel WK. Chronic relapsing (dysimmune) polyneuropathy: pathogenesis and treatment. Ann Neurol 1981;9 (suppl): 134-45.

"Pentland B. Azathioprine in chronic relapsing idiopathic polyneuropathy. Postgrad Med J 1980; 56:734-5.

12 Palmer KNY. Polyradiculoneuropathy treated with cytotoxic drugs. Lancet 1966;1:265.

13 Yuill GM, Swinburn WR, Liversedge LA. Treatment of polyneuropathy with azathioprine. Lancet 1970;2: 854-6.

14 Sivaram CA, Kapur S, Rao NS, Chopra JS. Infective polyneuritis treated with azathioprine. Neurology (India) 1975;12:111-4.

15 Heathfield K, Dallos V. Treatment of polyneuropathy with azathioprine. Lancet $1970 ; 2: 1030$.

16 Cendrowski W. Treatment of polyneuropathy with azathioprine and adrenal steroids. Acta Med Pol 1977;18:147-56.

17 Prusinski A, Szulc-Kuberska J, Zawadzki Z. A case of chronic Guillain-Barré syndrome treated successfully with azathioprine. Wiad Lek 1978;31:1545-7.

18 Walker GL. Progressive polyradiculoneuropathy. Treatment with azathioprine. Aust NZ J Med 1979;9:184-7. 